\title{
Thyrotoxic Periodic Paralysis Induced by Dexamethasone
}

\author{
Eun Ju Lee, Tae Kyoon Kim, Min Jeong Kwon, Soon Hee Lee, Jeong Hyun Park \\ Department of Internal Medicine, Inje University College of Medicine, Busan, Korea
}

Thyrotoxic periodic paralysis (TPP) is a disease characterized by sudden onset and muscle paralysis. It occurs in the setting of hypokalemia of thyrotoxicosis. Cases of TPP induced by a glucocorticoid such as prednisolone or methylprednisolone have been reported. We report on two patients, each of whom received a dexamethasone injection and subsequently developed TPP. Both patients experienced sudden, flaccid paralysis of both extremities after the injection but recovered completely after receiving a potassium replacement. Laboratory results revealed thyrotoxicosis. The patients were diagnosed with Graves' disease and discharged after receiving treatment with methimazole and propranolol. This report provides the clinical description of TPP induced by dexamethasone injection. These cases suggest that clinicians must consider the presence of hyperthyroid disease in patients who develop acute paralysis after treatment with a glucocorticoid, even in the absence thyrotoxic symptoms. Furthermore, physicians should be aware that TPP can occur even in response to dexamethasone used for treatment of thyrotoxic crisis or Graves' ophthalmopathy. (Endocrinol Metab 27:299-302, 2012)

Key Words: Dexamethasone, Hypokalemia, Paralysis, Thyrotoxicosis

\section{INTRODUCTION}

Thyrotoxic periodic paralysis (TPP) is a clinical syndrome characterized by recurrent and reversible muscle weakness. The condition is rare in Western populations but is relatively common amongst Asians, especially among men. The symptoms usually involve the lower limbs but may progress to the upper limbs and respiratory muscles in a severe attack; however, this is rare [1]. Attacks of weakness are commonly precipitated by meals high in carbohydrates, high-salt diets, and alcohol. These attacks may also occur during rest following prolonged exercise [1]. In addition, hypokalemia can be induced by glucocorticoid injection. Recently, cases of TPP induced by prednisolone or methylprednisolone were reported [2-5]. We report on two patients with TPP induced by dexamethasone injection.

\section{CASE REPORTS}

\section{Case 1}

A 37-year-old man visited the emergency department complain- ing of leg muscle weakness. He had previously developed a rash that covered his whole body, for which he had gone to a nearby hospital the day before, where he received an injection of $10 \mathrm{mg}$ dexamethasone. He woke early in the morning the next day with weakness in his lower extremities. He said that he had not experienced similar symptoms in the past. He had no history or family history of similar conditions. At the time of presentation to the emergency room, his body temperature was $36.8^{\circ} \mathrm{C}$; respiratory rate, 20/min; pulse rate, 109/min; and blood pressure, 120/80 $\mathrm{mmHg}$. He had an acute, ill-looking appearance but was mentally alert. He said that he had experienced no weight loss, heat intolerance, or excess sweating. Physical examination revealed that his thyroid gland was of normal size and contained no palpable mass. Neurologic examination revealed a muscle-strength level of two out of five in both lower extremities. The muscle strength of his upper extremities was normal, and deep tendon reflexes were diminished. Laboratory results revealed hypokalemia (serum potassium of 2.3 $\mathrm{mEq} / \mathrm{L}$ ) and normal serum creatinine kinase. His thyroid function test revealed thyrotoxicosis: thyroid stimulating hormone (TSH) level of $0.006 \mu \mathrm{IU} / \mathrm{mL}$ (reference, 0.27-4.20), triiodothyronine (T3)
Received: 12 March 2012, Accepted: 14 May 2012

Corresponding author: Min Jeong Kwon

Department of Internal Medicine, Inje University College of Medicine, 75 Bokji-ro, Busanjin-gu, Busan 614-735, Korea

Tel: +82-51-890-8743, Fax: +82-51-892-0273, E-mail: koma911@naver.com
Copyright (๑) 2012 Korean Endocrine Society

This is an Open Access article distributed under the terms of the Creative Commons Attribution Non-Commercial License (http://creativecommons.org/licenses/by-nc/3.0/) which permits unrestricted non-commercial use, distribution, and reproduction in any medium, provided the original work is properly cited. 
level of $171.6 \mathrm{ng} / \mathrm{dL}$ (reference, 80-200), and free thyroxine (fT4) level of $2.46 \mathrm{ng} / \mathrm{dL}$ (reference, 0.93-1.71). Further laboratory diagnostics showed an anti-thyroid peroxidase antibody (TPO Ab) level of 6.69 $\mathrm{IU} / \mathrm{mL}$ (reference, up to 34), TSH receptor Ab level of 11.9\% (reference, up to 15), and thyroid stimulating (TS) Ab level of 290.9\% (Table 1). Electrocardiogram showed sinus tachycardia and ST depression. Ultrasonographic examination showed that the thyroid gland was within the normal size range but that the thyroid parenchyma had coarse echogenicity. Thyroid uptake and technetium and radioactive iodine scanning also revealed a normal-sized thyroid, with increased technetium uptake and normal radioactive iodine uptake (19.2\% at 24 hours). We initially diagnosed diffuse toxic goiter due to the relatively decreased iodine uptake following steroid injection. The patient recovered fully after potassium re-

Table 1. Laboratory data on admission

\begin{tabular}{|c|c|c|}
\hline & Case 1 & Case 2 \\
\hline \multicolumn{3}{|l|}{ Blood chemistry } \\
\hline Total protein (g/dL) & 7.5 & 6.4 \\
\hline Albumin (g/dL) & 4.8 & 3.8 \\
\hline AST (U/L) & 18 & 31 \\
\hline ALT (U/L) & 27 & 32 \\
\hline $\mathrm{LDH}(\mathrm{mg} / \mathrm{dL})$ & 170 & 165 \\
\hline CPK (U/L) & 71 & 153 \\
\hline Glucose (mg/dL) & 209 & 150 \\
\hline BUN (mg/dL) & 12 & 25 \\
\hline Creatinine $(\mathrm{mg} / \mathrm{dL})$ & 0.62 & 0.79 \\
\hline $\mathrm{Na}(\mathrm{mEq} / \mathrm{L})$ & 140 & 142 \\
\hline $\mathrm{K}(\mathrm{mEq} / \mathrm{L})$ & 2.3 & 1.5 \\
\hline $\mathrm{Cl}(\mathrm{mEq} / \mathrm{L})$ & 109 & 105 \\
\hline $\mathrm{Ca}(\mathrm{mg} / \mathrm{dL})$ & 9.6 & 9.1 \\
\hline $\mathbb{P}(\mathrm{mg} / \mathrm{dL})$ & 1.1 & 3 \\
\hline Total cholesterol (mg/dL) & 177 & 161 \\
\hline Triglyceride (mg/dL) & 65 & 95 \\
\hline LDL-C (mg/dL) & 125 & 106 \\
\hline $\mathrm{HDL}-\mathrm{C}(\mathrm{mg} / \mathrm{dL})$ & 42 & 37 \\
\hline \multicolumn{3}{|l|}{ Thyroid function test } \\
\hline $\mathrm{TSH}(\mu \mathrm{lU} / \mathrm{mL})$ & 0.006 & $<0.005$ \\
\hline Thyronine (ng/dL) & 171.6 & 176 \\
\hline Free thyroxine (fT4) (ng/dL) & 2.46 & 3.29 \\
\hline Anti-TPO Ab (IU/mL) & 6.69 & $>1,000.00$ \\
\hline TSH receptor Ab (\%) & 11.9 & 20.7 \\
\hline Thyroid stimulating Ab (\%) & 290.9 & 384.4 \\
\hline
\end{tabular}

Ab, antibody; ALT, alanine aminotransferase; AST, aspartate aminotransferase; BUN, blood urea nitrogen; CPK, creatine phosphokinase; HDL-C, high density lipoprotein cholesterol; IP, phosphate; LDH, lactate dehydrogenase; LDL-C, low density lipoprotein cholesterol; TPO, thyroid peroxidase; TSH, thyroid stimulating hormone. placement. He was then diagnosed with Graves' disease and discharged after he was treated with methimazole and propranolol. In the 6 months since then, he has been taking methimazole and has not experienced paralysis.

\section{Case 2}

A 35-year-old man visited the emergency department complaining of muscle weakness in both the lower and upper extremities. Two years ago, he had been diagnosed with Graves' disease and been taking medication to treat it until 6 months before presenting to the emergency room. Two months before presenting to the emergency room, he had experienced back pain and a tingling sensation in both legs, for which he had gone to a nearby hospital. The orthopedist suspected disc herniation after inspection and injected $5 \mathrm{mg}$ dexamethasone. Thereafter, the patient had experienced weakness in his lower and upper extremities. Upon presenting to the emergency room, he said he had no history of similar paralysis, and there was no family history of muscle paralysis. His body temperature was $36.8^{\circ} \mathrm{C}$; respiratory rate, $20 / \mathrm{min}$; pulse rate, $98 / \mathrm{min}$; and blood pressure, 130/80 $\mathrm{mmHg}$. He had an acute, ill-looking appearance but was mentally alert. He said that he had experienced weight loss, heat intolerance, and excess sweating 2 months ago. Physical examination revealed a diffuse, enlarged thyroid. Neurological examination revealed muscle strength levels of two out of five in both the lower and upper extremities. Sensory function was normal. Laboratory results revealed hypokalemia (serum potassium of $1.5 \mathrm{mEq} / \mathrm{L}$ ) and normal serum creatinine kinase. His thyroid function test revealed thyrotoxicosis: TSH level of $<0.005 \mu \mathrm{IU} / \mathrm{mL}$ (reference, 0.27-4.20), T3 level of $176 \mathrm{ng} / \mathrm{dL}$ (reference, 80-200), fT4 level of $3.29 \mathrm{ng} / \mathrm{dL}$ (reference, 0.93-1.71). Further laboratory diagnostics showed a TPO Ab level of $>1,000.00 \mathrm{IU} / \mathrm{mL}$ (normal, up to 34), TSH receptor Ab level of $20.7 \%$ (normal, up to $15 \%$ ), and TS Ab level of $384.4 \%$ (Table 1). Electrocardiogram showed flat $\mathrm{T}$ wave, right bundle branch block, and ST depression. Ultrasonographic examination revealed diffuse goiter, heterogeneous hypoechoic gland, and increased blood flow. He recovered fully after potassium replacement. The patient was diagnosed with a recurrence of Graves' disease and was discharged after receiving treatment with methimazole and propranolol.

\section{DISCUSSION}

Periodic paralyses can result from various causes. Primary peri- 
odic paralyses are caused by a genetic defect, and secondary periodic paralyses can be the effect of drugs, adrenal gland disease (aldosteronism), or the misuse of laxatives or thiazides [2]. TPP is a well-known complication of thyrotoxicosis. It occurs in the setting of hypokalemia of thyrotoxicosis. Thyrotoxicosis is more common in women, but the male to female ratio of TPP ranges from 20:1 to $70: 1[1,2,6]$. Symptoms are usually confined to the lower extremities but may progress to the upper extremities in rare occasions. TPP can be diagnosed in patients with the characteristic symptoms of hypokalemia and thyrotoxicosis obtained from laboratory results. Symptoms of thyrotoxicosis may be mild. Attacks of weakness are commonly precipitated by meals high in carbohydrates, a high-salt diet, alcohol intake, and prolonged exercise [1]. Other risk factors include acetazolamide use, trauma, cold exposure, infection, menses, emotional stress, and steroid use [7]. Recently, cases of TPP induced by prednisolone or methylprednisolone use have been reported [2-5]. However, no cases of TPP induced by dexamethasone injection had been reported thus far.

The pathogenesis of TPP is not well understood. We do know that low potassium levels are caused by a rapid and massive shift of potassium into the cells. It is thought that this results from increased $\mathrm{Na}^{+} / \mathrm{K}^{+}$-ATPase pump activity in skeletal muscle, which is caused by the thyroid hormone [1]. In addition, $\mathrm{Na}^{+} / \mathrm{K}^{+}$-ATPase pump activity can be increased by direct stimulation with $\beta$-adrenergic hormones, insulin, insulin-like growth factor 1 , and amylin $[3,8,9]$. As a result, the enhanced adrenergic response caused by thyroid hormone exacerbates hypokalemia [1,3]. Glucocorticoid is uncommonly used to treat conditions such as thyrotoxic crisis or ophthalmopathy. When thyrotoxic patients are treated with glucocorticoid, it can induce hypokalemia by shifting potassium into the cells through several mechanisms $[4,5]$. These include steroid-induced hyperinsulinemia and an increased $\mathrm{Na}^{+} / \mathrm{K}^{+}$-ATPase pool in the skeletal muscle. Moreover, steroid treatment exacerbates hypokalemia by promoting the renal excretion of potassium, worsening muscle weakness. The mineralocorticoid effect of glucocorticoid is a well-known mechanism [4]. The present patient developed hypokalemia and weakness soon after glucocorticoid administration. The steroid- induced hyperinsulinemia increased the activity of the $\mathrm{Na}^{+} / \mathrm{K}^{+}$-ATPase in minutes and amylin, which is co-secreates with insulin is also stimulate the $\mathrm{Na}^{+} / \mathrm{K}^{+}$pump [9]. But, the direct effect on the the $\mathrm{Na}^{+}$/ $\mathrm{K}^{+}$pump of steroid appears slowly. And the low transtubular potassium gradient level in most papers about TPP indicated that renal potassium loss was not the primary cause of hypokalemia. There- fore, direct effect in skeletal muscle and mineralocorticoid effect of steroid can't explain the steroid-induced TPP. Dexamethasone which don't have a mineralocorticoid effect may cause paralysis due to this cause.

The pathophysiology of hypokalemic periodic paralysis include the mutation in transmembrane, voltage gated ion channels in skeletal muscle. These include mutations in the a-subunit of the dihydropyridine receptor (CACNA1S) and in the a-subunit of the sodium channel, SCN4A [2,9]. Also, there have been reports that genetic analysis revealed a point mutation of the KCNE3 potassium channel gene or CACNA1S calcium channel gene in TPP patients [4,10]. Hence attack in this case may be influenced by these gene mutation. The mechanism underlying TPP remains obscure. More study is needed to know about TPP.

TPP does not recur once the patient is euthyroid. So, the mainstay of therapy is adequate control of hyperthyroidism. The use of nonselective beta-blockers with antithyroid drugs during early treatment can be helpful. Potassium supplementation as prophylaxis when the patient has a normal serum potassium level is ineffective [1]. If paralysis appears before receiving the diagnosis of hyperthyroidism, TPP is hard to prevent. But, if the patient have paralysis symptom after steroid use, we should consider the possibility of thyrotoxicosis. If we need to use steroid to patient with thyrotoxicosis in an emergency situation, we should check potassium. Simultaneously, potassium replacement may be helpful.

\section{요 약}

갑상선 중독성 주기 마비는 주로 하지에 국한되는 이완성 마비로 양측성으로 나타나며 현저한 저칼륨혈증을 동반하는 질환이다. Prednisolone이나 methylprednisolone에 의한 갑상선 중독성 주기 마비는 보고되고 있다. 저자들은 덱사메타손 주사 후에 발생한 하 지마비를 주소로 내원한 갑상선 중독증 환자 2예를 경험하였기에 이를 보고하는 바이다.

이 증례는 덱사메타손 주사 이후 근무력감을 호소하는 환자에 있 어서 갑상선 중독 증상이 없더라도 갑상선 질환의 가능성을 고려해 야 함을 시사하고 있다. 또한 갑상선 위기나 갑상선 안구병증의 치 료로 사용되는 덱사메타손에 의해서도 갑상선 중독성 주기 마비가 발생할 수 있음을 보여주고 있다.

\section{REFERENCES}

1. Kung AW: Clinical review: thyrotoxic periodic paralysis: a diagnostic 
challenge. J Clin Endocrinol Metab 91:2490-2495, 2006

2. Hagel S, Elznerova T, Dietrich W, Schrauzer T, John S: Chest pain and paralysis after pulse prednisolone therapy an unusual case presentation of thyrotoxic periodic paralysis: a case report. Cases J 2:7501, 2009

3. Tessier JJ, Neu SK, Horning KK: Thyrotoxic periodic paralysis (TPP) in a 28-year-old sudanese man started on prednisone. J Am Board Fam Med 23:551-554, 2010

4. Miyashita Y, Monden T, Yamamoto K, Matsumura M, Kawagoe N, Iwata C, Banba N, Hattori Y, Kasai K: Ventricular fibrillation due to severe hypokalemia induced by steroid treatment in a patient with thyrotoxic periodic paralysis. Intern Med 45:11-13, 2006

5. Wongraoprasert S, Buranasupkajorn P, Sridama V, Snabboon T: Thyrotoxic periodic paralysis induced by pulse methylprednisolone. Intern Med 46: 1431-1433, 2007

6. Li W, Changsheng C, Jiangfang F, Bin G, Nanyan Z, Xiaomiao L, Deq- iang L, Ying X, Wensong Z, Qiuhe J: Effects of sex steroid hormones, thyroid hormone levels, and insulin regulation on thyrotoxic periodic paralysis in Chinese men. Endocrine 38:386-390, 2010

7. Atallah P, Dib ER, Khoury M: Thyrotoxic periodic paralysis. A case report. J Med Liban 55:167-169, 2007

8. Chang JH, Kim CS, Park JK, Park J, Cho MH, Ahn CW, Kim KR: A case of hypokalemic perodic paralysis induced by hyperinsulinemia. Korean J Med 68:692-696, 2005

9. Arzel-Hezode M, McGoey S, Sternberg D, Vicart S, Eymard B, Fontaine B: Glucocorticoids may trigger attacks in several types of periodic paralysis. Neuromuscul Disord 19:217-219, 2009

10. Dias Da Silva MR, Cerutti JM, Arnaldi LA, Maciel RM: A mutation in the KCNE3 potassium channel gene is associated with susceptibility to thyrotoxic hypokalemic periodic paralysis. J Clin Endocrinol Metab 87: 4881-4884, 2002 